\title{
TINGKAT KETERGANTUNGAN NELAYAN GILLNET DI KARANGSONG, KABUPATEN INDRAMAYU TERHADAP SUMBERDAYA IKAN
}

\section{(DEPENDENCY OF GILLNET FISHER IN KARANGSONG, INDRAMAYU TO FISH RESOURCES)}

\author{
Iin Solikhin ${ }^{1,2}$, Eko Sri Wiyono ${ }^{2}$ dan Akhmad Solihin ${ }^{2}$ \\ ${ }^{1}$ Corresponding author \\ 2 Departemen Pemanfaatan Sumberdaya Perikanan \\ Fakultas Perikanan Dan Ilmu Kelautan, Institut Pertanian Bogor \\ E-mail: iinsolikhin.psp46@gmail.com
}

\begin{abstract}
Fishermen have a high level dependency on fish resources. Therefore, it is necessary to make a job diversification as an alternative income. However, to diversify the job, it is necessary to analyze the dependency level of fishermen on fish resources. The purpose of this research are (1) to describe gillnet fisheries in PPI Karangsong, (2) to analyze the dependency level of fishermen in PPI Karangsong on fish resources. Using cryterias of number of families, time allocation, income, and expenses dependency level ofishermen were calculated using Multi Cryteria Analysis (MCA). The result of this stydy showed that gillnet fishermen in Karangsong coastal fishing port is dominated by gillnet 0-10 GT group. Gillnet ship which less than 25 GT is still using ice to preserve the fish, while the bigger ship $(\geq 25$ GT) already using freezer. Dependency level of fishermen who operated gillnet $<20$ GT is higher than gillnet $>20$ GT.
\end{abstract}

Keywords: Dependency, fishermen, gillnet, Indramayu, Karangsong

\begin{abstract}
ABSTRAK
Ketergantungan nelayan terhadap sumberdaya ikan pada umumnya memiliki tingkat ketergantungan yang tinggi. Oleh karena itu, diperlukan adanya diversifikasi pekerjaan sebagai sumber pendapatan alternatif saat ikan susah didapatkan. Namun untuk melakukan diversifikasi pekerjaan tersebut, maka perlu dilihat terlebih dahulu tingkat ketergantungan nelayan terhadap sumberdaya ikan. Tujuan dari penelitian ini yaitu (1) mendeskripsikan perikanan gillnet di PPI Karangsong, (2) menganalisis tingkat ketergantungan nelayan gillnet di PPI Karangsong terhadap sumberdaya ikan. Perhitungan tingkat ketergantungan menggunakan Multi Cryteria Analysis dengan kriteria yang digunakan yaitu jumlah keluarga, alokasi waktu, pendapatan, dan pengeluaran. Perikanan gillnet di PPI Karangsong didominasi oleh kelompok gillnet 0-10 GT. Kapal gillnet < 25 GT masih menggunakan es, sedangkan kapal $\geq 25$ GT menggunakan freezer. Tingkat ketergantungan nelayan gillnet 0-20 GT terhadap sumberdaya ikan lebih tinggi dibandingkan dengan nelayan gillnet $>20$ GT.
\end{abstract}

Kata kunci: Gillnet, Indramayu, ketergantungan, nelayan, PPI Karangsong

\section{PENDAhUluan}

Ketergantungan nelayan terhadap sumberdaya ikan pada umumnya memiliki tingkat ketergantungan yang tinggi. Namun untuk memanfaatkan sumberdaya ikan ini, nelayan harus menghadapi resiko yang tinggi seperti resiko keselamatan kerja dan ketidakpastian hasil tangkapan yang tinggi. Saat musim paceklik, nelayan sering kali mengalami kesusahan untuk menangkap ikan di laut dan bahkan tidak mendapatkan ikan sama sekali. Selain itu, nelayan juga tidak dapat melaut karena cuaca buruk. Sehingga saat musim paceklik nelayan sering kali tidak berpenghasilan. Hal tersebut disebabkan oleh adanya ketergantungan nelayan terhadap sumberdaya ikan yang tinggi. Kondisi tersebut juga dialami oleh nelayan di PPI Karangsong.

PPI Karangsong merupakan salah satu pelabuhan perikanan yang memiliki aktivitas perikanan yang teramai di Indramayu. Berdasarkan data produksi ikan dari tahun 2007-2010 yang dikeluarkan oleh Dinas Kelautan dan Perikanan Indramayu (2010), PPI Karangsong memiliki produksi ikan yang tertinggi dibandingkan dengan pelabuhan perikanan lain yang ada di Indramayu. Banyaknya produksi ikan tersebut didominasi oleh produksi dari unit penangkapan gillnet. Berdasarkan data unit penangkapan ikan dari Dinas 
Kelautan dan Perikanan Indramayu (2010), unit penangkapan ikan yang ada di PPI Karangsong mayoritas unit penangkapan gillnet. Sekitar $80 \%$ dari total unit penangkapan ikan yang ada di PPI Karangsong merupakan unit penangkapan gillnet dengan ukuran kapal yang beragam. PPI Karangsong yang dikelola oleh KPL Mina Sumitra ini juga pernah menjadi pelabuhan perikanan terbaik di Jawa Barat. Sehingga penulis tertarik untuk mendeskripsikan keragaan perikanan gillnet yang ada di PPI Karangsong dan menganalisis tingkat ketergantungan nelayan gillnet terhadap sumberdaya ikan.

Nelayan gillnet di PPI Karangsong mengalami kesulitan untuk mendapatkan ikan saat musim paceklik. Bahkan beberapa nelayan gillnet di PPI Karangsong tidak melakukan operasi penangkapan ikan saat musim paceklik. Sehingga nelayan tidak mempunyai penghasilan, karena tidak mendapatkan ikan. Upaya yang dapat dilakukan untuk mengatasi permasalahan tersebut yaitu dengan diversifikasi pekerjaan agar nelayan gillnet di PPI Karangsong mempunyai sumber pendapatan alternatif. Namun untuk melakukan diversifikasi pekerjaan tersebut, maka perlu dilihat terlebih dahulu tingkat ketergantungan nelayan gillnet terhadap sumberdaya ikan. Sehingga penelitian tentang deskripsi sistem perikanan gillnet dan tingkat ketergantungan nelayan gillnet terhadap sumberdaya ikan di PPI Karangsong penting dilakukan untuk mengetahui kelompok nelayan gillnet mana yang harus lebih diprioritaskan dalam melakukan diversifikasi pekerjaan. Tujuan dari penelitian ini adalah menganalisis tingkat ketergantungan nelayan gillnet di PPI Karangsong terhadap sumberdaya ikan.

\section{METODE PENELITIAN}

Penelitian dilaksanakan pada bulan Maret sampai April 2013, bertempat di Pangkalan Pendaratan Ikan (PPI) Karangsong, Kabupaten Indramayu, Jawa Barat. Bahan yang digunakan terdiri dari kuesioner, nelayan gillnet, dan data sekunder. Alat yang dipakai dalam penelitian ini terdiri dari alat pengukur panjang dengan skala $1 \mathrm{~mm}$, laptop, kamera, dan alat tulis. Metode penelitian yang digunakan adalah studi kasus. Metode penentuan sampel dilakukan dengan menggunakan purposive sampling. Analisis perikanan gillnet dilakukan secara deskriptif dan analisis tingkat ketergantungan menggunakan Multi Criteria Analysis (MCA). Kriteria yang digunakan dalam penelitian ini yaitu: jumlah anggota keluarga yang terlibat dalam bidang penangkapan ikan, alokasi waktu untuk melaut, persentase pendapatan rumah tangga nelayan dari bidang penangkapan ikan, dan persentase pengeluaran rumah tangga nelayan untuk penangkapan ikan.

\section{HASIL DAN PEMBAHASAN}

\subsection{Sistem Perikanan Gillnet 3.1.1. Konstruksi Gillnet}

Konstruksi gillnet di PPI Karangsong sama seperti gillnet pada umumnya. Sebagaimana yang diungkapkan oleh Subani dan Barus (1989) bahwa bagian-bagian utama pada jaring insang, yaitu pelampung (float) dan tali pelampung (float line), tali ris atas dan tali ris bawah, badan jaring (webbing atau net), pemberat (sinker) dan tali pemberat (sinker line atau lead line), serta srampad (selvedge). Ukuran dan jumlah bagian-bagian tersebut bergantung pada posisi pengoperasiannya di dalam laut. Demikian juga dengan gillnet yang ada di PPI Karangsong. Gillnet di PPI Karangsong dibuat dari bahan polyamide monofilament dengan serat pilinan 8-12 ply berwarna putih transparan agar tidak mudah terlihat oleh ikan. Ukuran mata jaring yang digunakan yaitu 3.25-4 inchi. Pelampung jaring terbuat dari bahan polyurethane, dengan jumlah pelampung 25 buah per piece dengan jarak antar pelampung $3 \mathrm{~m}$. Pelampung umbul yang digunakan terbuat dari bahan plastik atau styrofoam. Jarak antar pelampung umbul 25 meter dengan jumlah dalam satu piece 3 buah. Sedangkan untuk pelampung tanda digunakan bahan polyurethane yang diikatkan pada sebuah tongkat kayu dengan panjang 3 meter yang telah diberi tanda berupa bendera atau lampu. Pemberat yang digunakan terbuat dari semen cor berbentuk lingkaran pipih dengan diameter $8 \mathrm{~cm}$ tebal $5 \mathrm{~cm}$ dan berat 400 
gram. Pemberat dipasang dengan jarak 9 meter. Tali ris yang digunakan terbuat dari bahan tambang PE multifilament dengan panjang $75 \mathrm{~m}$ dan diameter 6 $\mathrm{mm}$.

\subsubsection{Nelayan Gillnet}

Jumlah nelayan tiap kapal gillnet tidaklah sama, tergantung pada ukuran kapal yang digunakan dalam operasi penangkapan ikan. Hal ini juga sama seperti yang diungkapkan oleh Miranti (2007) yaitu jumlah nelayan tiap kapal gillnet tidaklah sama, tergantung pada skala usaha tersebut. Dalam operasi penangkapan gillnet biasanya dioperasikan oleh 2-5 orang nelayan untuk kapal yang berukuran 0-10 GT, 6-12 orang nelayan untuk kapal berukuran 11-30 GT, dan 10-14 orang nelayan untuk kapal berukuran > 30 GT. Sistem bagi hasil nelayan gillnet yang diterapkan di PPI Karangsong untuk kapal yang berukuran < 25 GT yaitu 50\% untuk pemilik dan 50\% untuk ABK. Nahkoda mendapat bagian 1,5 kali lebih besar dari pendapatan per-ABK. Sedangkan untuk kapal yang berukuran $\geq 25$ GT yaitu $60 \%$ untuk pemilik dan $40 \%$ untuk ABK. Nahkoda kapal mendapat 2 kali lebih besar dari pendapatan perABK.

\subsection{Metode Pengoperasian Alat Tangkap}

Gillnet di PPI Karangsong umumnya dioperasikan pada malam hari. Pengoperasiannya dibagi dalam empat tahap yaitu: persiapan, penentuan fishing ground, pengoperasian alat tangkap (setting, soaking, dan hauling), dan penyortiran serta pemindahan hasil tangkapan ke dalam palka. Metode pengoperasian gillnet di Karangsong tersebut sama seperti pengoperasian gillnet yang diungkapkan oleh Miranti (2007) yang menyatakan bahwa secara umum metode pengoperasian alat tangkap gillnet terdiri atas beberapa tahap, yaitu :

1) Persiapan yang dilakukan nelayan meliputi pemeriksaan alat tangkap, kondisi mesin, bahan bakar kapal, perbekalan, es dan tempat untuk menyimpan hasil tangkapan.

2) Pencarian daerah penangkapan ikan (DPI).

3) Pengoperasian alat tangkap yang terdiri atas pemasangan jaring (sett- ing), perendaman jaring (soaking), dan pengangkatan jaring (hauling).

4) Penanganan hasil tangkapan.

\subsubsection{Kapal Gillnet}

Kapal gillnet yang beroperasi di PPI Karangsong adalah kapal berbahan dasar kayu dan digolongkan berdasarkan ukuran kapal yaitu 0-10 GT, 11-30 GT, dan >30 GT. Banyak trip per bulan untuk kapal 3 GT dan 6 GT sebanyak 20-30 kali tergantung pada musim dengan lama trip 1-2 hari dan rata-rata dalam satu tahun melakukan 210 trip. Kapal 20 GT lama tripnya 14-20 hari dan rata-rata dalam satu tahun melakukan 14 trip. Kapal 30 GT lama tripnya 30-40 hari dan rata-rata dalam satu tahun melakukan 7 trip. Kapal 34 GT lama tripnya 30-40 hari dan ratarata dalam satu tahun melakukan 7 trip. Kapal 40 GT lama tripnya 40-60 hari dan rata-rata dalam satu tahun melakukan 5 trip. Kapal dengan ukuran $\geq 25$ GT di wilayah PPI Karangsong umumnya telah menggunakan mesin pendingin (freezer).

\subsubsection{Biaya Operasi}

Biaya operasi unit penangkapan gillnet di Karangsong bersumber dari pemilik kapal. Biaya operasi yang dibutuhkan pada kegiatan operasi penangkapan ikan dengan menggunakan gillnet terdiri dari biaya solar, biaya perbekalan es, dan makanan. Banyaknya solar yang dibutuhkan untuk kapal yang berukuran 3 GT sebanyak 30 liter dan kapal berukuran 6 GT membutuhkan solar sebanyak 50 liter dengan lama trip 1-2 hari. Sedangkan biaya untuk ransum/perbekalan pada kapal berukuran 3 GT sebesar Rp 145.000 dan 6 GT sebesar Rp 346.000. Kapal berukuran 20 GT membutuhkan solar sebanyak 1.200 liter dengan lama trip 20 hari dan biaya perbekalannya Rp 7.044.000 per trip. Kapal berukuran 30 GT membutuhkan solar sebanyak 5.000 liter dengan lama trip 30 hari dan biaya perbekalannya Rp 23.083.000 per trip. Kapal berukuran 34 GT membutuhkan solar sebanyak 6.000 liter dan biaya perbekalannya $\mathrm{Rp}$ 24.080.000 per trip. Sedangkan kapal berukuran 40 GT membutuhkan solar sebanyak 8.000 liter dengan lama trip 40 hari dan biaya perbekalannya $\mathrm{Rp}$ 64.015.000 per trip. 


\subsection{Daerah dan Musim Penangkapan}

Musim penangkapan ikan dengan menggunakan gillnet di PPI Karangsong tergolong menjadi tiga musim yaitu musim puncak, musim sedang, dan musim paceklik. Daerah penangkapan ikan untuk gillnet < 25 GT yaitu perairan Indramayu, Cirebon, Ciasem, Jakarta, dan Jawa Tengah. Musim puncak untuk gillnet $<25$ GT terjadi pada bulan Agustus hingga bulan November, musim sedang terjadi bulan Maret hingga Juli, dan musim paceklik terjadi bulan Desember hingga Februari. Daerah penangkapan ikan untuk gillnet $\geq 25$ GT yaitu laut Jawa, perairan Sumatera, perairan Kalimantan, dan selat Karimata. Musim puncak untuk gillnet $\geq 25$ GT terjadi pada bulan Februari sampai bulan Juni. Musim sedang terjadi pada bulan Juli sampai bulan November, sedangkan musim paceklik untuk gillnet $\geq 25$ GT terjadi bulan Desember hingga bulan Januari.

\subsection{Hasil Tangkapan}

Hasil tangkapan yang diperoleh dari unit penangkapan gillnet di PPI Karangsong terdiri dari hasil tangkapan utama dan hasil tangkapan sampingan. Hasil tangkapan utama gillnet di Karangsong yaitu tongkol (Auxisthazard) sebanyak 40,36\%, tenggiri (Scomberomorus commersoni) sebanyak 12,66\%, manyung (Arius thalassinus) sebanyak $15,81 \%$, dan remang (Congresox talabon) sebanyak 11,52\%. Hasil tangkapan sampingan yaitu $3,23 \%$ bawal hitam (Formio niger), 1,97\% klayaran (Makaira indica), $0,92 \%$ alamkao (Psettodes erumeri), 4,6\% cucut (Carcharhinus sp.), 0,46\% pari (Dasyatis sp.), 0,47\% kakap putih (Lates calcarifer), 0,82\% blidah (Chirocentrus dorab), 5\% kakap merah (Lutjanus malabaricus), 0,52\% krempul (Caranx sexfasciatus), dan 1,65\% ikan campur. Persentase berikut diperoleh dari hasil rata-rata produksi ikan di PPI Karangsong selama lima tahun terakhir yaitu dari tahun 2008-2012 yang diproduksi dengan menggunakan alat tangkap gillnet.

\subsection{Kriteria Ketergantungan Nelayan Gillnet Terhadap SDI}

\subsubsection{Jumlah Keluarga}

Banyaknya anggota keluarga yang bekerja di sektor perikanan dan non perikanan berdasarkan kelompok gillnet dapat dilihat pada Tabel 1.

Berdasarkan Tabel 1 dapat diketahui bahwa rata-rata jumlah anggota keluarga yang bekerja di sektor perikanan sangat rendah. Jika dalam suatu keluarga terdapat anak yang sudah dewasa, rata-rata hanya satu orang saja yang ikut bekerja dalam bidang perikanan. Hal ini sama seperti yang diungkapkan oleh Irnayasari (2009) yang melakukan penelitian serupa di Kabupaten Garut. Ia menyatakan bahwa rata-rata jumlah anggota keluarga yang bekerja di sektor perikanan tangkap sangat rendah. Hal ini dikarenakan anggota keluarga nelayan, khususnya anak nelayan sebagian besar masih balita dan duduk dibangku sekolah. Jika dalam satu keluarga terdapat anak yang sudah dewasa, rata-rata hanya satu orang yang akan meneruskan usaha penangkapan keluarga. Hasil perhitungan kriteria jumlah keluarga dengan menggunakan fungsi nilai disajikan pada Tabel 2.

Berdasarkan Tabel 2 terlihat bahwa kelompok nelayan gillnet 3 GT dan 6 GT memiliki tingkat ketergantungan yang paling tinggi terhadap sumberdaya ikan dengan nilai 1 . Sehingga kelompok nelayan gillnet 3 GT dan 6 GT berdasarkan kriteria jumlah keluarga yang tergabung dalam bidang perikanan dapat dikatakan kelompok nelayan gillnet yang memiliki ketergantungan terhadap sumberdaya ikan yang paling tinggi dibandingkan dengan kelompok nelayan gillnet lainnya.

\subsubsection{Alokasi Waktu}

Besarnya alokasi waktu nelayan untuk menangkap ikan dan kegiatan lainnya disajikan pada Tabel 3. Berdasarkan Tabel 3 dapat diketahui bahwa rata-rata dalam satu tahun nelayan mengalokasikan waktunya untuk menangkap ikan sebesar 67\%. Nelayan gillnet 3 GT dan 6 GT memiliki alokasi waktu melaut yang paling sedikit dibandingkan dengan kelompok nelayan gillnet yang lainnya. Kelompok nelayan gillnet 20 GT memiliki alokasi waktu melaut yang paling tinggi dibandingkan yang lainnya. Kelompok nelayan gillnet 20 GT memiliki waktu persiapan melaut dan aktivitas bongkar muat yang lebih singkat. Sehingga kelompok nelayan gillnet 20 GT memiliki alokasi waktu 
untuk melaut yang lebih banyak dibandingkan dengan kelompok nelayan gillnet 30 GT, 34 GT, dan 40 GT. Alokasi waktu selain menangkap ikan digunakan nelayan untuk perbaikan alat tangkap, perbaikan kapal, bongkarmuat, persiapan perbekalan melaut, dan istirahat. Perhitungan standarisasi kriteria alokasi waktu dengan fungsi nilai dapat dilihat pada Tabel 4 .

Tabel 1. Jumlah keluarga nelayan gillnet

\begin{tabular}{ccc}
\hline Kelompok gillnet & Perikanan (orang) & Non Perikanan (orang) \\
\hline 3 GT & 1 & 2 \\
$6 \mathrm{GT}$ & 1 & 2 \\
$20 \mathrm{GT}$ & 0 & 3 \\
$30 \mathrm{GT}$ & 0 & 3 \\
$34 \mathrm{GT}$ & 0 & 3 \\
$40 \mathrm{GT}$ & 0 & 3 \\
\hline
\end{tabular}

Tabel 2. Hasil perhitungan standarisasi kriteria jumlah keluarga dengan fungsi nilai

\begin{tabular}{lcccccc}
\hline Kelompok gillnet & 3 GT & 6 GT & 20 GT & 30 GT & 34 GT & 40 GT \\
\hline Keluarga (orang) & 1 & 1 & 0 & 0 & 0 & 0 \\
TK & 1 & 1 & 2 & 2 & 2 & 2 \\
\hline
\end{tabular}

Tabel 3. Alokasi waktu melaut

\begin{tabular}{ccc}
\hline Kelompok gillnet & Melaut (hari) & Tidak Melaut (hari) \\
\hline 3 GT & 210 & 150 \\
6 GT & 210 & 150 \\
20 GT & 280 & 80 \\
30 GT & 245 & 115 \\
34 GT & 245 & 115 \\
40 GT & 250 & 110 \\
\hline
\end{tabular}

Tabel 4. Hasil perhitungan standarisasi kriteria waktu melaut dengan fungsi nilai

\begin{tabular}{lcccccc}
\hline Kelompok gillnet & 3 GT & 6 GT & 20 GT & 30 GT & 34 GT & 40 GT \\
\hline Waktu & 0 & 0 & 1 & 0,5 & 0,5 & 0,5714 \\
TK & 4 & 4 & 1 & 3 & 3 & 2 \\
\hline
\end{tabular}

Berdasarkan fungsi nilai kriteria alokasi waktu pada Tabel 4, maka kelompok gillnet 20 GT menjadi kelompok yang paling tergantung terhadap ketersediaan sumberdaya ikan dengan fungsi nilai 1, karena kelompok ini memiliki alokasi waktu melaut dalam satu tahun yang paling tinggi dibandingkan kelompok lainnya. Tertinggi kedua yaitu kelompok gillnet 40 GT dengan fungsi nilai 0,5714 . Ketiga yaitu kelompok nelayan gillnet 30 GT dan 34
GT dengan nilai 0,5. Keempat yaitu kelompok nelayan gillnet 3 GT dan 6 GT yang ditetapkan sebagai nilai yang minimum dengan fungsi nilai 0 .

\subsubsection{Pendapatan Nelayan}

Besarnya pendapatan rumah tangga nelayan dari perikanan dan non perikanan disajikan pada Tabel 5 .

Berdasarkan Tabel 5 dapat diketahui bahwa hanya kelompok nelayan gillnet 3 GT dan 6 GT yang mempunyai 
pendapatan dari sektor non perikanan. Hal tersebut dikarenakan masih adanya anak nelayan yang sudah dewasa dan bisa bekerja dalam rumah tangga nelayan tersebut. Sedangkan untuk anak nelayan gillnet $\geq 20$ GT, sebagian besar masih balita dan masih sekolah. Hal tersebut disebabkan karena nelayan gillnet $\geq 20$ GT yang memang masih berusia rata-rata 30 tahun. Sehingga belum mempunyai anak yang dewasa dan mampu bekerja. Perhitungan standarisasi kriteria pendapatan rumah tangga nelayan dengan fungsi nilai disajikan pada Tabel 6.

Berdasarkan Tabel 6 dapat diketahui bahwa kelompok nelayan gillnet $\geq 20$ GT memiliki ketergantungan yang paling tinggi terhadap sumberdaya ikan dengan fungsi nilai 1. Hal tersebut dikarenakan pendapatan rumah tangga nelayan gillnet $\geq 20$ GT hanya dari sektor perikanan. Sedangkan kelompok nelayan gillnet 3 GT dan 6 GT memiliki tingkat ketergantungan terhadap sumberdaya ikan yang lebih rendah dibandingkan dengan kelompok nelayan gillnet $\geq 20$ GT yaitu dengan fungsi nilai 0 . Hal ini dikarenakan kelompok nelayan gillnet 3 GT dan 6 GT mempunyai sumber pendapatan lain selain dari sektor perikanan.

\subsubsection{Pengeluaran Nelayan}

Besarnya pengeluaran nelayan untuk kegiatan perikanan dan non perikanan disajikan pada Tabel 7 .

Tabel 5. Persentase pendapatan rumah tangga nelayan gillnet

\begin{tabular}{ccc}
\hline Kelompok gillnet & \% Perikanan & \% Non Perikanan \\
\hline 3 GT & 74,4681 & 25,5319 \\
6 GT & 77,0335 & 22,9665 \\
20 GT & 100 & 0 \\
30 GT & 100 & 0 \\
34 GT & 100 & 0 \\
40 GT & 100 & 0 \\
\hline
\end{tabular}

Tabel 6. Hasil perhitungan standarisasi kriteria pendapatan dengan fungsi nilai

\begin{tabular}{ccc}
\hline Kelompok gillnet & Pendapatan & TK \\
\hline 3 GT & 0 & 3 \\
6 GT & 0,1005 & 2 \\
20 GT & 1 & 1 \\
$30 \mathrm{GT}$ & 1 & 1 \\
34 GT & 1 & 1 \\
40 GT & 1 & 1 \\
\hline
\end{tabular}

Tabel 7. Persentase pengeluaran rumah tangga nelayan gillnet

\begin{tabular}{ccc}
\hline Kelompok Gillnet & \% Perikanan & \% Non Perikanan \\
\hline 3 GT & 72,0388 & 27,9612 \\
6 GT & 73,6505 & 26,3495 \\
20 GT & 48,4765 & 51,5235 \\
30 GT & 54,5657 & 45,4343 \\
34 GT & 55,1867 & 44,8133 \\
40 GT & 55,5556 & 44,4444 \\
\hline
\end{tabular}


Berdasarkan Tabel 7 terlihat bahwa kelompok nelayan gillnet 3 GT dan 6 GT mempunyai alokasi pengeluaran untuk perikanan yang paling tinggi dibandingkan dengan kelompok gillnet yang lainnya. Hal tersebut disebabkan oleh adanya anak nelayan yang ikut bekerja di sektor perikanan dan juga sudah tidak mempunyai tanggungan biaya anak sekolah. Sehingga alokasi pengeluaran kelompok gillnet 3 GT dan 6 GT memiliki alokasi pengeluaran untuk perikanan yang lebih tinggi dibandingkan pengeluaran rumah tangga nelayan gillnet lainnya. Sehingga pengeluaran untuk non perikanan lebih kecil dibandingan dengan pengeluaran nelayan gillnet $\geq 20$ GT yang masih mempunyai tanggungan biaya anak sekolah. Perhitungan standarisasi kriteria pengeluaran rumah tangga nelayan dengan fungsi nilai disajikan pada Tabel 8.

Berdasarkan Tabel 8 terlihat bahwa kelompok nelayan gillnet 6 GT memiliki tingkat ketergantungan terhadap sumberdaya ikan yang paling tinggi dengan nilai 1 dan tertinggi kedua yaitu kelompok nelayan gillnet 3 GT dengan nilai 0,9360 . Sedangkan untuk nelayan gillnet $\geq 20$ GT memiliki tingkat ketergantungan terhahap sumberdaya ikan yang lebih rendah dari kelompok gillnet 3 GT dan 6 GT. Hal ini dikarenakan tidak adanya anak nelayan yang ikut bekerja dalam sektor perikanan dan kelompok nelayan gillnet $\geq 20$ GT masih mempunyai tanggungan biaya anak sekolah. Sehingga alokasi pengeluaran rumah tangga nelayan untuk sektor perikanan menjadi lebih kecil dibandingkan dengan kelompok nelayan gillnet 3 GT dan 6 GT yang tidak lagi mempunyai tanggungan biaya anak sekolah.

\subsubsection{Kriteria Gabungan}

Fungsi nilai dari masing-masing kelompok nelayan gillnet untuk keempat kriteria tersebut di atas, disajikan pada Tabel 9.

Berdasarkan Tabel 9 terlihat bahwa kelompok nelayan gillnet 6 GT mempunyai tingkat ketergantungan terhadap sumberdaya ikan yang paling tinggi dengan nilai 2,1005. Tingkat ketergantungan tertinggi kedua yaitu kelompok nelayan gillnet 20 GT dengan nilai 2 . Ketiga adalah kelompok nelayan gillnet
3 GT dengan nilai 1,9360 yang masih tergolong memiliki tingkat ketergantungan terhadap sumberdaya ikan yang tinggi dari kelompok gillnet yang lain. Keempat adalah kelompok nelayan gillnet 40 GT dengan nilai 1,8526. Kemudian kelima adalah kelompok nelayan gillnet 34 GT dengan nilai 1,7666. Terakhir yang keenam adalah kelompok nelayan gillnet 30 GT yang memiliki tingkat ketergantungan yang terendah dengan nilai 1,7419 .

Hasil analisis ini menunjukkan bahwa tingkat ketergantungan nelayan terhadap sumberdaya ikan berbedabeda. Tidak ada kecenderungan bahwa semakin rendah ukuran perahu otomatis akan mempunyai tingkat ketergantungan yang lebih tinggi. Hal ini berkaitan dengan latar belakang keluarga nelayan yang mengoperasikannya dan kondisi lingkungan dimana gillnet akan dioperasikan.

Perikanan gillnet di PPI Karangsong didominasi oleh unit penangkapan gillnet 0-10 GT. Unit penangkapan gillnet yang berukuran kurang dari 20 GT tidak dapat beroperasi sepanjang tahun karena adanya pengaruh musim dan cuaca, sedangkan kapal yang berukuran $\geq 20$ GT dapat beroperasi sepanjang tahun karena tidak dipengaruhi musim dan cuaca. Kapal gillnet yang berukuran kurang dari 25 GT masih menggunakan es, sedangkan kapal gillnet yang berukuran $\geq 25$ GT sudah menggunakan freezer.

Urutan dari yang tertinggi sampai yang terendah tingkat ketergantungan nelayan gillnet di PPI Karangsong terhadap sumberdaya ikan adalah sebagai berikut: kelompok nelayan gillnet 6 GT dengan nilai 2,1005; gillnet 20 GT dengan nilai 2 ; gillnet 3 GT dengan nilai 1,9360 ; gillnet 40 GT dengan nilai 1,8526; gillnet 34 GT dengan nilai 1,7666; dan gillnet 30 GT dengan nilai 1,7419. Berdasarkan peringkat tersebut disimpulkan bahwa kelompok nelayan gillnet $\leq 20$ GT lebih membutuhkan adanya diversifikasi pekerjaan dibandingkan dengan kelompok nelayan gillnet $>20$ GT. Hal tersebut dikarenakan kelompok nelayan gillnet $\leq 20$ GT memiliki sensitivitas perekonomian keluarga yang lebih tinggi terhadap ketersediaan sumberdaya ikan. 
Tabel 8. Hasil perhitungan standarisasi kriteria pengeluaran dengan fungsi nilai

\begin{tabular}{ccc}
\hline Kelompok gillnet & Pengeluaran & TK \\
\hline 3 GT & 0,936 & 2 \\
6 GT & 1 & 1 \\
$20 \mathrm{GT}$ & 0 & 6 \\
$30 \mathrm{GT}$ & 0,2419 & 5 \\
$34 \mathrm{GT}$ & 0,2666 & 4 \\
$40 \mathrm{GT}$ & 0,2812 & 3 \\
\hline
\end{tabular}

Tabel 9. Kriteria gabungan

\begin{tabular}{lrrrrrr}
\hline \multicolumn{1}{c}{ Kriteria } & 3 GT & 6 GT & 20 GT & 30 GT & 34 GT & 40 GT \\
\hline Keluarga & 1 & 1 & 0 & 0 & 0 & 0 \\
Waktu & 0 & 0 & 1 & 0,5 & 0,5 & 0,571 \\
Pendapatan & 0 & 0,1005 & 1 & 1 & 1 & 1,000 \\
Pengeluaran & 0,936 & 1 & 0 & 0,2419 & 0,2666 & 0,281 \\
\hline \multicolumn{1}{c}{ Jumlah } & 1,936 & 2,1005 & 2 & 1,7419 & 1,7666 & 1,852 \\
\hline \multicolumn{1}{c}{ TK } & 3 & 1 & 2 & 6 & 5 & 4 \\
\hline
\end{tabular}

\section{KESIMPULAN DAN SARAN}

\subsection{Kesimpulan}

Berdasarkan hasil penelitian ini dapat disimpulkan bahwa berdasarkan ukurannya, tingkat ketergantungan nelayan terghadap nelayan berbeda-beda. Secara umum, semakin kecil ukuran perahu yang digunakan, ketergantungan nelayan terhadap sumberdaya ikan juga semakin besar.

\subsection{Saran}

Saran yang diusulkan dari hasil penelitian adalah:

1) Nelayan yang memiliki tingkat ketergantungan tinggi terhadap sumberdaya ikan, perlu diberikan alternatif pekerjaan lain sebagai sumber pendapatan tambahan saat ikan susah dicari.

2) Perlu adanya bimbingan atau pelatihan kepada keluarga nelayan baik dalam bidang penangkapan ikan atau pun bidang non penangkapan ikan, sehingga nelayan memiliki kemampuan dan keahlian yang lain.

\section{DAFTAR PUSTAKA}

Basri, Hasan. 2009. Pengaruh Kecepatan Arus Terhadap Tampilan Gillnet: Uji Coba di Flume Tank [Skripsi]. Bogor: Departemen Pemanfaatan Sumberdaya Perikanan, Fakultas Perikanan dan Ilmu Kelautan, Institut Pertanian Bogor.

Dinas Kelautan dan Perikanan Kabupaten Indramayu. 2008. Data Unit Penangkapan Ikan di PPI Karangsong. Indramayu: DKP Indramayu.

Dinas Kelautan dan Perikanan Kabupaten Indramayu. 2010. Data Potensi Armada Indramayu. Indramayu: DKP Indramayu.

Hasan I. 2004. Analisis Data Penelitian dengan Statistik. Jakarta: Bumi Aksara.

Irnayasari. 2009. Ketergantungan Nelayan terhadap Usaha Penangkapan Ikan di PPP Cilauteureun Kabupaten Garut [Skripsi]. Bogor: Fakultas Perikanan dan Ilmu Kelautan, Institut Pertanian Bogor.

KKP. 2011. Statistik Perikanan Tangkap Indonesia 2010. Jakarta: Direktorat Jendral Perikanan Tangkap, Kementrian Kelautan dan Perikanan. 
Miranti. 2007. Perikanan Gillnet di Palabuhanratu [Skripsi]. Bogor: Departemen Pemanfaatan Sumberdaya Perikanan, Fakultas Perikanan dan Ilmu Kelautan, Institut Pertanian Bogor. 8-9 hal.

Subani W dan HR Barus. 1989. Alat Penangkapan Ikan dan Udang Laut Indonesia. Jurnal Penelitian Perikanan Laut No. 50. Jakarta: Departemen Pertanian, Balai Penelitian Perikanan Laut. 245 hal. 